\title{
Cultural Heritage and Ownership
}

Ph.d.-seminar arrangeret $i$ et samarbejde mellem forskerskolerne MAST og Kulturarvens forskerskole

\section{Syddansk Universitet, Campus Esbjerg, 20.-22. november 2006.}

\author{
Carina Ren* og Mette Guldberg*
}

Title: Cultural heritage and Ownership. PhD seminar

Abstract: On 20-22 November 2006, a PhD seminar on cultural heritage and ownership was arranged by the Research School for Studies in Maritime and Coastal Environment, Heritage and Sustainable Tourism (MAST) and the Danish Research School of Cultural Heritage. The seminar was hosted by the University of Southern Denmark, Campus Esbjerg and aimed at presenting different perspectives on cultural heritage in current international research. Lecturers and PhDs from Denmark, Sweden, Norway, England, Poland, Portugal and Israel fully demonstrated the broad range of approaches. In spite of a great variety in contributions from history, anthropo$\log$, archaeology, ethnology, tourism studies, conservation studies and engineering, many shared themes could be identified, such as how cultural heritage can be (mis) used in both the experience economy and tourism, in the construction of identities and within nation states. Themes such as inclusion and exclusion through selection and classification, the idea of felt and formal ownership, and the notion of authenticity where also discussed.

These last 10-20 years have seen an enormous spread of the notion of cultural heritage and its very broad use, to the point where an adequate definition no longer seems possible. Even though emphasis on our historic inheritance can be positive, it is also crucial to undertake scholarly debate and discus why and how the notion is used and appli$e d$. The contributors to the seminar, both lecturers and PhDs, managed to demonstrate that scholarly diversity is no obstacle to mutual inspiration and fruitful contributions to a shared, critical stance in the field of cultural heritage.

Keywords: Cultural heritage, ownership, authenticity, inclusion and exclusion, tourism, experience economy, identity, nation state, cross disciplinary, research school. 
Kulturarv kan handle om mange ting. Om identitet, om nationalstaten, om oplevelsesøkonomi, men også om forvaltning, indsamling og bevaring. Kulturarven kan betragtes som et politisk magtredskab, en økonomisk ressource eller som instrument til opnåelse af eksistentiel autenticitet. Perspektivet afhænger af, hvem du spørger. Dette blev til fulde bekræftet på Syddansk Universitet, hvor Campus Esbjerg var vært for et ph.d.-seminar arrangeret af Kulturarvens forskerskole og MAST - Research School for Studies in Maritime and Coastal Environment, Heritage and Sustainable Tourism. Det engelsksprogede seminar bar titlen Cultural Heritage and Ownership. Ideen med denne titel var at tiltrække stipendiater med problemstillinger af både faglig, politisk, administrativ og ledelsesmæssig karakter. Det overordnede mål var at skabe et bedre overblik over den aktuelle, internationale og fagligt vidtspændende forskning inden for kulturarvsfeltet. Desuden var ønsket på den baggrund at forsøge at udpege en eller flere røde tråde i den, som vi skal se, meget brede tilgang til og forståelse af kulturarv. I det følgende vil vi forsøge at opsummere, evaluere og tænke videre ud fra de erfaringer, som blev høstet på seminaret.

Målgruppen for seminarets deltagere var ph.d.-studerende, der på forskellig vis beskæftiger sig med kulturarv, enten analytisk, empirisk eller konkret. De i alt 17 deltagende ph.d.-studerende fra Danmark, Sverige, Portugal, England, Israel og Polen havde deres rødder inden for fagtraditioner som historie, arkæologi, konservering, etnologi og antropologi, men også ingeniøren samt flere forskere inden for turismemanagement og -marketing var mødt frem. Alt i alt var der skabt forventninger til en noget blandet forsamling med potentielt ikke-sammenfaldende eller direkte modsatrettede interesser og forståelser af begrebet kulturarv.

Seminaret blev åbnet af den gennemgående kommentator, direktør Carsten Paludan-Müller, Norsk Institutt for Kulturminneforskning (NIKU), som blandt andet påpegede, at begrebet kulturarv er konstrueret $\mathrm{i}$ forbindelse med nationalstatens opståen og er kommet tilbage i søgelyset i de senere år, bl.a. fordi nationalstaten flere steder udfordres. Gennem seminaret var der desuden forelæsninger af professor Marie Louise Stig Sørensen, Cambridge University, der talte om kulturarv i et nationalt perspektiv, og dr. Kevin Meethan, University of Plymouth, der påpegede vigtigheden af at skelne mellem analytiske modeller af kultur og nationale og lokale modeller af kultur. Professor Peter Aronsson, University of Linköping, talte om ejerskab til kulturarv, og dr. Janne Liburd, Syddansk Universitet, fortalte med udgangspunkt i studier på De Vestindiske Øer om udfordringer til kulturarven. Alle disse forelæsninger lå på kursets første to dage og dannede baggrund og referenceramme for de følgende dages fremlæggelser og diskussioner, hvori også flere af forelæserne deltog.

13 af de deltagende ph.d.-studerende havde før seminarets start indleveret et paper, som de i løbet af seminaret havde 30 minutter til at fremlægge, få respons af en på forhånd udvalgt respondent samt svare på spørgsmål fra salen. I løbet af seminaret blev der præsenteret projekter, der spændte fra videnskabsteoretiske begrebsanalyser over analyser af forvaltningen af kulturarven til de overvejelser, konkrete konserveringsopgaver medfører.

Flere af projekterne behandlede kulturarven og turismen, som dermed blev belyst fra mange forskellige vinkler: Avitan Biran fremlagde overvejelser om, hvordan man formidler 
112 en by som Jerusalem, der rummer så mange forskellige fortællinger af vital men forskellig betydning for de mange grupper af turister, der besøger byen. Tilsvarende behandlede Mads Daubjerg ejerskabet til det flernationale mindesmærke Dybbøl Banke og til historien omkring det. Med udgangspunkt i Liverpool beskæftigede Christina Kokosalakis sig med forbruget af kultur i byens turistlandskab,

Maciek Kronenberg arbejdede med industrisamfundets kulturarv i turismen, og Josefine Østrup behandlede mad som identitetsgivende og dermed som en del af kulturarven, der kan formidles til turister. Carina Ren beskæftigede sig med forholdet mellem turisme og kulturarv i det polske turistområde Zakopane, og endelig talte Bente Bramming om polariteten mellem tid og rum og autenticitetsbegrebet i kulturarvsturisme.

Et par deltagere analyserede den måde, kulturarven forvaltes på: Mette Bjerrum arbejdede med den måde, hvorpå den nationale kulturarv klassificeres og Mille Gabriel berettede om repatrieringen af tidligere indlemmet kulturarv fra andre lande. Andre to fremlagde overvejelser $\mathrm{i}$ forbindelse med konserveringsprojekter: Inge Rörig Dalgaard fortalte om metoder til bevaring af kalkmalerier og Marisa Pamplona fremlagde overvejelser om autenticitet $\mathrm{i}$ forbindelse med restaurering af stenbygninger. Endelig beskæftigede Stefan Pajun sig med genstandenes rolle $\mathrm{i}$ identitetsdannelsen $\mathrm{i}$ senmiddelalderens kystsamfund og Abi Hunt med, hvordan ændringerne i Lincolnshires landbrug 1930 til 2000 afspejler sig i områdets museer.

Som medvirkende kommentator var det utroligt inspirerende at høre de mange spændende projekter fremlagt på kompetent vis. Trods de meget forskellige baggrunde, de studerende kom fra, og trods de meget forskellig- artede emner, viste det sig alligevel muligt at føre en fælles meningsfyldt diskussion ud fra det fælles omdrejningspunkt - kulturarven samtidig med at de forskellige faglige baggrunde kunne befrugte hinanden, give nye vinkler på kendt stof og bringe nye synspunkter i spil.

Der var flere tilbagevendende temaer gennem dagene. Et af dem var brugen af kulturarven, dels som et led i nationalstatsdannelsen eller som identitetsgivende for etniske mindretal, dels som en ressource, som indgår i oplevelsesøkonomien, og dermed kan bruges og nogle gange misbruges - af turistindustrien. Et andet tema var betydningen af den måde, hvorpå man arbejder med kulturarv: Udpegninger og klassifikationer indeholder ofte et element af inklusion af visse dele af befolkningen og eksklusion af andre. Hvem har eller føler ejerskab til det, der udpeges til kulturarv?

Et tredje tema var spørgsmålet om autenticitet: er tingene autentiske, når de først er blevet restaureret, udpeget, afgrænset, formidlet og fortolket - og autentiske i forhold til hvad?

Kulturarv er i dag kommet på dagsordenen $i$ et omfang, som man ikke gjorde sig forestilling om for 10-20 år siden. Mens det på den ene side er glædeligt, at der sættes fokus på den overleverede del af fortiden - den være sig materiel eller immateriel - er det på den anden side vigtigt, at der også foregår en kvalificeret, faglig diskussion om den måde, kulturarven anvendes på. Ordet kulturarv er blevet en del af dagligsproget, hvor det bliver brugt om stort set alt, hvad der hidrører fra fortiden, ofte som en slags slagord, der kan sætte ekstra vægt bag argumenter. Vi er langt ud over det punkt, hvor det synes realistisk at opstille en fælles definition af begrebet.

På den baggrund var det glædeligt at erfare, 
at studerende med så forskellige indfaldsvink-

ler til feltet, alligevel havde så meget at bidrage med til hinandens projekter, og at alle gik til opgaven med en kritisk sans. Og netop den kritiske sans er vigtig at holde fast i som forskningens adelsmærke. Det er vigtigt, at der sideløbende med de mange forvaltningsprojekter inden for kulturarvsområdet også holdes fast i en analytisk og problemorienteret tilgang i den diskussion, der er så vigtig for den faglige udvikling.

${ }^{*}$ Carina Ren, Ph.d.-studerende

Adresse: Center for turisme, innovation og kultur/Syddansk Universitet

Niels Bohrs vej 9

DK-6700 Esbjerg

E-mail:ren@sitkom.sdu.dk

${ }^{*}$ Mette Guldberg, Museumsinspektør, ph.d.

Adresse: Center for Maritime og Regionale Studier, Fiskeri-og Søfartsmuseet/Syddansk

Universitet, Tarphagevej 2, DK-6710 Esbjerg V

E-mail:mg@fimus.dk 